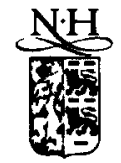

ELSEVIER

Journal of International Economics 39 (1995) 201-226

\title{
Intra-industry trade: A Heckscher-Ohlin-Ricardo approach
}

\author{
Donald R. Davis \\ Department of Economics, Harvard University, Cambridge, MA 02138, USA \\ Received February 1994, revised version received March 1995
}

\begin{abstract}
The large volume of intra-industry trade is often cited as a critical element favoring trade theories based on increasing returns and imperfect competition over those with constant returns and perfect competition. The former provide an elegant account of intra-industry trade, while the latter, it is often argued, cannot. This paper provides an account of intra-industry trade based squarely on comparative advantage. The key is to introduce elements of Ricardian trade theory within the Heckscher-Ohlin framework. This is appropriate, as essential characteristics of intra-industry trade imply that technical differences matter. Increasing returns, in short, are not necessary for intra-industry trade.
\end{abstract}

Key words: Intra-industry trade; Heckscher-Ohlin; Ricardian; Technological differences; Trade patterns

JEL classification: F11

\section{Introduction}

In a recent survey article, Leamer (1992) noted that since the Leontief paradox only one empirical finding fundamentally altered the way economists view the causes of international trade-the demonstration by Grubel and Lloyd (1975) of the importance of intra-industry trade. The content of this change is indicated by Helpman and Krugman (1989), who cite the prevalence of intra-industry trade as "one of the key empirical reasons for emphasizing the role of increasing returns and imperfect competition in the world economy". 
The traditional theories of comparative advantage, based on constant returns to scale and perfect competition, were perceived to be incapable of explaining intra-industry trade. By contrast, the scale economies model offers a very simple account: even absent comparative advantage, scale economies motivate specialization within industries and so intra-industry trade. The elegance and power of the theory have earned it wide acceptance.

Empirical verification of the role of scale economies in giving rise to intra-industry trade, however, has proven elusive. Tests based on the Grubel-Lloyd measure of intra-industry trade have consistently shown a significant negative relation between intra-industry trade and proxies for scale economies. ${ }^{1}$ A recent test seeking to account for import shares by proxies for scale economies found a positive relation by some measures and a negative relation by another. ${ }^{2}$ The evidence advanced in Helpman's (1988) study of fourteen developed countries does not distinguish between a variety of models with specialization. ${ }^{3}$ In sum, the direct empirical support of the scale economies theory is, at best, mixed.

In this paper, I argue that the conditions that characterize intra-industry trade in fact allow an extremely simple account of this trade based on comparative advantage. The essential insight is that these conditions bring to the fore traditional Ricardian determinants of trade. I develop this in a setting that allows for both Ricardian and Heckscher-Ohlin influences, providing a unified account of intra-industry and inter-industry trade.

The logic is simply outlined. The key to inducing intra-industry trade is to have intra-industry specialization across countries. Scale economies provide one reason for such specialization. Yet they are not the only reason. The

\footnotetext{
${ }^{1}$ See Loertscher and Wolter (1980), Caves (1981), Balassa and Bauwens (1987), and Marvel and Ray (1987). Loertscher and Wolter had anticipated a positive coefficient based on a contrast between constant returns sectors, lacking intra-industry trade, with scale economies sectors, where it should be prevalent. Ex post they surmised that if scale economies are too strong that production might need to be concentrated in one or a few locales, inhibiting intra-industry trade, a suggestion that has been followed by Caves and Balassa and Bauwens. Marvel and Ray demurred, arguing that, "It is an interesting commentary on the power of ideas over evidence that Loertscher and Wolter were willing to reinterpret their variables in light of their results in order to support the monopolistic competition model." I view it more cautiously. Theory suggests that some degree of scale economies is necessary to induce specialization and trade; beyond this there should be a range in which scale economies are unrelated to the volume of intra-industry trade; and only when the scale economies force great concentration of production should it start to reduce this trade. It is perhaps not surprising that the cross-industry regressions ultimately shed little light on this. In any case, the lack of a theoretical alternative to the scale economies approach made the reinterpretation of the theory to conform with the scale economies approach a natural exercise.

${ }^{2}$ See Harrigan (1991).

${ }^{3}$ See Markusen and Wigle (1990) and Leamer (1992).
} 
emphasis on specialization is suggestive of Ricardian trade patterns; but consideration of technical differences as a reason for trade requires some motivation specific to the problem of intra-industry trade.

The essence of Ricardian theory is that technical differences matter for trade patterns when expansion of an individual sector does not drive up marginal opportunity costs. Two characteristics make intra-industry trade precisely such a setting. The first is the very definition of intra-industry trade-trade in goods of similar factor intensity. It is evident that substitution possibilities across such goods in production will be excellent. The second is the emphasis within the intra-industry trade literature on the large number of goods produced and traded. When the number of goods is large relative to the number of factors, some sectors may be expanded and others contracted without rising marginal opportunity cost. Both of these characteristics of intra-industry trade thus suggest the relevance of Ricardian determinants of trade.

The theoretical problem addressed may also have important implications for trade policy. The empirical importance of intra-industry trade, and the perceived inability of the traditional theories to account for it, have been taken as key pieces of evidence in favor of the increasing returns theory. Increasing returns, of course, are often associated with imperfect competition. Yet I show that intra-industry trade could arise, per the traditional theories, even if returns to scale are constant and markets perfectly competitive. A determination of the cause of this trade would then have important implications for appropriate trade policy, which depends critically on the underlying market structure.

In addition, this account of intra-industry trade provides a sound theoretical foundation for the large body of empirical work, including CGE modeling, that has employed the assumptions of constant returns and perfect competition. ${ }^{4}$

The organization of this paper is as follows. Section 2 reviews prior discussions of intra-industry trade and comparative advantage. Section 3 shows that the very definition of intra-industry trade suggests the relevance of Ricardian determinants of trade. This is developed in an ideal case of trade in what I call "perfectly-intraindustry" goods. Section 4 develops the

\footnotetext{
${ }^{4}$ This empirical work could not ignore intra-industry trade; yet neither could it reconcile such trade with the assumed theoretical structure. The problem was finessed via the Armington assumption-that consumers perceive otherwise identical goods produced in different locales to be different goods. Yet it begged the question of why, for example, "french" goods have to be produced in France. If this account has some plausibility for perfume or wine, it is plainly incredible as an account of most intra-industry trade. The Armington assumption was an ad hoc device to ensure intra-industry specialization, so intra-industry trade (see Markusen and Wigle, 1990). By contrast, the model developed here departs from the standard framework only by adding features intrinsic to intra-industry trade.
} 
simplest possible framework that can give a unified account of inter-industry and intra-industry trade, while allowing direct comparability with the standard factor proportions results. Section 5 then examines the significance of the emphasis in the intra-industry trade literature on the variety and number of goods produced. This is shown, as well, to suggest the relevance of traditional Ricardian determinants of trade. The final section concludes.

\section{Intra-industry trade and comparative advantage}

In the last decade, there has been wide acceptance of a claim that traditional trade theories, based on comparative advantage, cannot account for observed intra-industry trade. Lancaster (1980) emphasized the large volume of intra-industry trade between similar countries as a puzzle:

'Intra-industry trade on a large scale, an undeniable fact of trade between modern industrial economies, is simply not a prediction of traditional trade theories.'

Helpman and Krugman (1985) stress the trade in goods of similar factor content as a mystery:

'.. trade patterns seem to include substantial two-way trade in goods of similar factor intensity. This 'intraindustry' trade seems both pointless and hard to explain from the point of view of a conventional trade analysis.'

Balassa and Bauwens (1988) make the claim bluntly:

'Theorists of intra-industry trade hold that economies of scale are a sine qua non condition of intra-industry specialization; in the absence of scale economies, all product varieties could be produced domestically and no intra-industry trade would take place.'

Krugman and Obstfeld (1991) extend this explicitly to the Ricardian model:

'.. the Ricardian model neglects the possible role of economies of scale as a cause of trade, which leaves it unable to explain the large trade flows between apparently similar nations ...'

The claims may be synthesized: traditional trade theories have difficulty accounting for a large volume of trade between countries which are similar in factor endowments and technology, a large share of which is in "differentiated" goods of similar factor intensity.

\subsection{Previous efforts}

Previous efforts to reconcile observed intra-industry trade with the theory 
of comparative advantage have fallen into three main areas. The first has focused on problems of aggregation. Finger (1975) and Chipman (1985) argued that existing classifications place goods of heterogeneous factor proportions in a single industry, and so intra-industry trade is unremarkable. While all observers acknowledge that actual industrial classification does not mesh neatly with the theoretical demarcation of industries, most would argue this does not eliminate the puzzle since intra-industry trade is important down to quite fine levels of disaggregation. A distinct explanation offered by Chipman (1988) is based on the theoretical properties of aggregation. Given any division of $N$ goods into fewer than $N$ industries, it is possible to find a division of world factor endowments between countries such that all trade is intra-industry trade. This remains possible even as countries have very similar endowment proportions. Surprisingly, no restriction on the basis for aggregation is required. The weakness of this account is that as countries come to have more similar endowments, the volume of trade converges to zero.

The second approach, developed by Falvey and Kierzkowski (1987), attempts to divorce the question of trade in differentiated products from the strong assumption that all varieties are produced under identical technical conditions. In their model, goods are distinguished on the demand side according to perceived quality, and on the production side by the fact that high quality goods are produced under conditions of greater capital intensity. While this accounts for trade in differentiated goods, some such as Brander (1987) have noted there is "some question as to whether the phenomenon Falvey models should be regarded as intra-industry trade". In effect, the question of trade in goods of similar factor intensity is sidestepped.

A third strand-the one on which the present paper builds-relies on the substitution possibilities across goods inherent in intra-industry trade. The origins of this work may be traced to Samuelson's (1948) article on factor price equalization, in which he noted that if both goods have the same factor intensity, then the transformation curve is linear. This is continued in the two-good, two-factor setting by Lizondo, Johnson and Yeh (1981), who demonstrate that as production functions become more similar, the PPF becomes "flatter". Grubel and Lloyd (1975, p.88) recognized the relevance of the shape of the PPF, and that this would make trade sensitive to technical differences, but then proceeded to bury the essential insight amidst a discursion on product cycle and other neo-technology theories of trade. More recently, Chipman (1985) and Rodgers (1988) have examined this in a setting of higher dimension of both goods and factors, by grouping goods into industries based on a Euclidean metric defined on the Cobb-Douglas production elasticities. They are then equipped to carry out a variety of comparative statics, including a demonstration that as the production functions of goods in an industry become closer (by the metric), intra- 
industry trade rises. Finally, this strand also includes the important, and neglected, piece by Vanek and Bertrand (1971). They noted that if there are more goods than factors, the world transformation surface has flats, which makes trade sensitive to technical differences. This is discussed further in Section 5 .

\section{Trade in perfectly-intraindustry goods}

In thinking about the sources of intra-industry trade, it is convenient to begin with an ideal case. As noted above, the theoretical literature defines intra-industry trade as exchange of goods of similar factor intensity. ${ }^{5}$

Consider, then, trade in goods which, at any common factor prices, have identical factor intensity. Call these "perfectly-intraindustry" goods. ${ }^{6}$ The essential properties of perfectly-intraindustry goods may be appreciated by focusing on the position of the respective isoquants. The key is that the isoquants of perfectly-intraindustry goods differ by a Hicks-neutral shift. If we allow cross-country technical differences which are themselves Hicksneutral, and which are non-uniform across goods, then the magnitude of that shift differs across countries. The fact that the isoquants of perfectlyintraindustry goods differ by a Hicks-neutral shift means that their marginal rate of transformation is constant. If the magnitude of that shift differs across countries, then so must the constant marginal rates of transformation.

As this suggests, the paradigmatic example of intra-industry trade is the textbook Ricardian model. ${ }^{7}$ Since there is a single factor, the goods are trivially perfectly-intraindustry goods. Still, two essential and related charac-

\footnotetext{
${ }^{5}$ See quotes above from Helpman and Krugman, and Brander. Actual industrial classification includes similarity of characteristics in both production and consumption (cf. Grubel and Lloyd, 1975, p.86 and Lloyd in Tharakan, 1989a, pp.19-22). However, the traditional trade thcorics are largcly agnostic rcgarding substitution possibilities in consumption (emphasizing only homotheticity of preferences). Thus this poses no challenge to the traditional theories. This is why the literature has focused, as noted, on intra-industry trade as trade in goods of similar factor intensity.

${ }^{6}$ Virtually all of the increasing returns literature on intra-industry trade has used the case of perfectly-intraindustry goods-either by positing a single factor in this sector or by having all varieties produced with identical production functions. See Krugman (1979), Lancaster (1980), and Helpman and Krugman (1985, chapters 7 and 8). The latter assumption has at times been justified by examples of varieties such as trade in red and green pencils. It should be kept in mind, however, that the empirical work that has motivated this theoretical work has maintained a significant degree of aggregation. Even at what is considered a highly disaggregated level-say five digit SITC (e.g. "photocopying appliances ")-the assumption of identical technologies across varieties is very strong.

${ }^{7}$ The Ricardian model is paradigmatic for the constant returns case of intra-industry trade not only, as emphasized here, because of trade in perfectly-intraindustry goods, but also because it is a case with more goods than factors. See Section 5 ,
} 
teristics will extend to a more general setting: as production is shifted from one good to the other, there is no rising marginal opportunity cost. Because of this, technical differences-however small-induce specialization in at least one of the countries, and trade. ${ }^{8}$

This can be extended simply to the standard two-good, two-factor, Heckscher-Ohlin model. As has long been recognized, ${ }^{9}$ when both sectors use the same factor intensity, the transformation curve is linear. With perfectly-intraindustry goods, factor intensities in the two sectors will always be the same, at any factor prices, and for any factor endowments. If there are small Hicks-neutral technical differences between countries, which are non-uniform across goods, then there must be specialization in at least one country, and so trade. This insight extends without alteration to the case with an arbitrary number of goods and factors (Ethier, 1984). Let there be $N$ goods and $M$ factors. Consider one country's matrix of optimal technical coefficients:

$$
A(\omega)=\left[\begin{array}{llll}
A_{1} & A_{2} & \ldots & A_{N}
\end{array}\right]=\left[\begin{array}{cccc}
a_{11} & a_{12} & \ldots & a_{1 N} \\
a_{21} & a_{22} & \ldots & a_{2 N} \\
\cdot & \cdot & \cdot & \cdot \\
a_{M 1} & a_{M 2} & \ldots & a_{M N}
\end{array}\right]
$$

Each column of $A(\omega)$ represents the optimal unit input coefficients for a single good. If the columns of $A(\omega)$ are linearly independent, then it is impossible, by definition, to express any one column as a linear combination of other columns. That is, at constant factor prices (and so unchanged coefficients), it is literally impossible for the other sectors to release factors in exactly the proportion in which they are used in an expanding sector. Expansion of the production of any one good requires that it bid up the price of factors that it uses intensively, and so yields a rising marginal opportunity cost of the good in terms of any other set of goods. This is what gives us the typical bowed-out feature of the PPF.

However, if goods 1 and 2 are perfectly-intraindustry goods, this argument fails. In this case, $A_{1}=\lambda A_{2}$ for some $\lambda$. If there are cross-country technical differences in these goods that motivate the expansion of one of these sectors, the other can release factors in precisely the proportion used in the expanding sector, and so without rising marginal opportunity cost. Thus technical differences-however small-will induce specialization and trade.

\footnotetext{
${ }^{8}$ Note that, in principle, this implies neither more nor less specialization than that associated with increasing returns technologies.

${ }^{9}$ See, for example, Samuelson (1948).
} 


\section{The Heckscher-Ohlin-Ricardo model}

This section develops the simplest possible model that gives a unified account of intra-industry and inter-industry trade, while allowing a clear contrast with the standard factor proportions results. ${ }^{10}$ This requires a model with three goods: two to represent intra-industry goods, and one the other industry. For comparability with standard results, we require a model with two factors, capital and labor. We allow there to exist arbitrarily small cross-country technological differences.

The interaction of factor proportions and technical differences in giving rise to the trade pattern leads us to call this the Heckscher-Ohlin-Ricardo model.

\subsection{The model}

There are three goods, $X_{1}, X_{2}$ and $Y$. The first two are perfectlyintraindustry goods, which means that for all factor price ratios they are produced under identical factor intensity. ${ }^{11}$ This allows us to unambiguously make the assumption that the intra-industry goods are capital-intensive relative to $Y$. We assume that technologies are identical across countries in $X_{2}$ and $Y$, with a small Hicks-neutral productivity difference in $X_{1}$, as reflected in:

Country One:

$$
X_{1}=A F\left(K_{X 1}, L_{X 1}\right) \quad X_{2}=F\left(K_{X 2}, L_{X 2}\right) \quad Y=G\left(K_{Y}, L_{Y}\right)
$$

\section{Country Two:}

$$
X_{1}=F\left(K_{X 1}, L_{X 1}\right) \quad X_{2}=F\left(K_{X 2}, L_{X 2}\right) \quad Y=G\left(K_{Y}, L_{Y}\right)
$$

where we assume $A>1$. Let preferences be identical and homothetic. ${ }^{12}$ Good $X_{2}$ is the numeraire.

\footnotetext{
${ }^{10}$ The extension of the fundamental result-the possibility of accounting for intra-industry trade between countries with similar endowment proportions-to a world with many countries, goods and factors is straightforward.

${ }^{11}$ Introduction of neutral Ricardian technical differences to a Heckscher-Ohlin framework has previously been suggested on empirical grounds by Minhas (1962), and for theoretical purposes by Bhagwati (1964) and Woodland (1982). Ruffin (1988) devised a distinct admixture of the theories, supposing countries differ in their endowments of "winemakers" and "clothmakers", where technical coefficients differ across types, but not across countries. However, in each case, they were interested in a set of issues distinct from intra-industry trade.

${ }^{12}$ An assumption maintained throughout this paper.
} 


\subsection{Replicating the integrated equilibrium}

Let us begin by developing the integrated equilibrium. ${ }^{13}$ Since there is an absolute technical advantage in the production of good $X_{1}$, only the technology of country One can be used in production of this good. Since the marginal rate of transformation between our intra-industry goods is constant, positive production of both goods requires that $P_{X 1}=1 / A$. The relative price $P_{Y}$ emerges from the general equilibrium. This gives rise to factor intensities $k_{X 1} \equiv k_{X 2}>k_{Y}$, and establishes a factor price ratio $w / r$. The exact allocation of factors to the various production sectors is determined.

Let $\bar{V}$ be the world factor endowment, and $\left(V^{1}, V^{2}\right)=\left[\left(K^{1}, L^{1}\right),\left(K^{2}, L^{2}\right)\right]$ be a partition. Let $\bar{V}(i)=[(\bar{K}(i), \bar{L}(i))]$ be the integrated equilibrium use of factors in sector $i$. The $\lambda_{i j}$ are shares for country $j$ of the integrated equilibrium production of good $i$. The Factor Price Equalization (FPE) set in this case is:

$$
\begin{aligned}
F P E= & \left\{\left(V^{1}, V^{2}\right) \mid \exists \lambda_{X_{2} 1}, \lambda_{X_{2} 2}, \lambda_{Y_{1}}, \lambda_{Y_{2}}, \geqslant 0\right. \\
& \text { such that } \lambda_{X_{2} 1}+\lambda_{X_{2} 2}=1, \quad \lambda_{Y_{1}}+\lambda_{Y_{2}}=1, \quad \lambda_{X_{1} 1}=1, \quad \lambda_{X_{12}}=0, \\
& \left.V^{1}=\sum_{i} \lambda_{i 1} \bar{V}(i) \quad V^{2}=\sum_{i} \lambda_{i 2} \bar{V}(i)\right\}
\end{aligned}
$$

This says that FPE is the set of partitions of world factor endowments, such that when employing the integrated equilibrium techniques:

- Production of the goods in which technologies are identical $\left(X_{2}\right.$ and $\left.Y\right)$ can be apportioned among the countries.

- Country One can produce the entire integrated equilibrium supply of the good $X_{1}$ in which it has a technical advantage.

- This is consistent with full employment of factors in each country.

This has a simple geometric interpretation (see Fig. 1). Country One must have sufficient factors to produce the integrated equilibrium supply of $X_{1}$

\footnotetext{
${ }^{13}$ The integrated equilibrium has been defined as the resource allocation that would occur if both goods and factors were perfectly mobile. An obvious element of the integrated equilibrium is factor price equalization. Consideration of the integrated equilibrium allows us to construct the set of partitions of world factor endowments that allow countries to attain all of the benefits of the fully integrated world by trade in goods alone. This will be called the Factor Price Equalization set. For our purposes, the convenience is that this also allows a simple analysis of trade patterns. The conception of trade as replicating this ideal construct appeared as a parable in Samuelson (1949). Dixit and Norman (1980) coined the term, and showed that the concept could be a powerful analytic tool. Helpman and Krugman (1985) followed this lead, making it a central element in their extremely lucid presentation of both standard and new trade theory.
} 
The Integrated Equilibrium

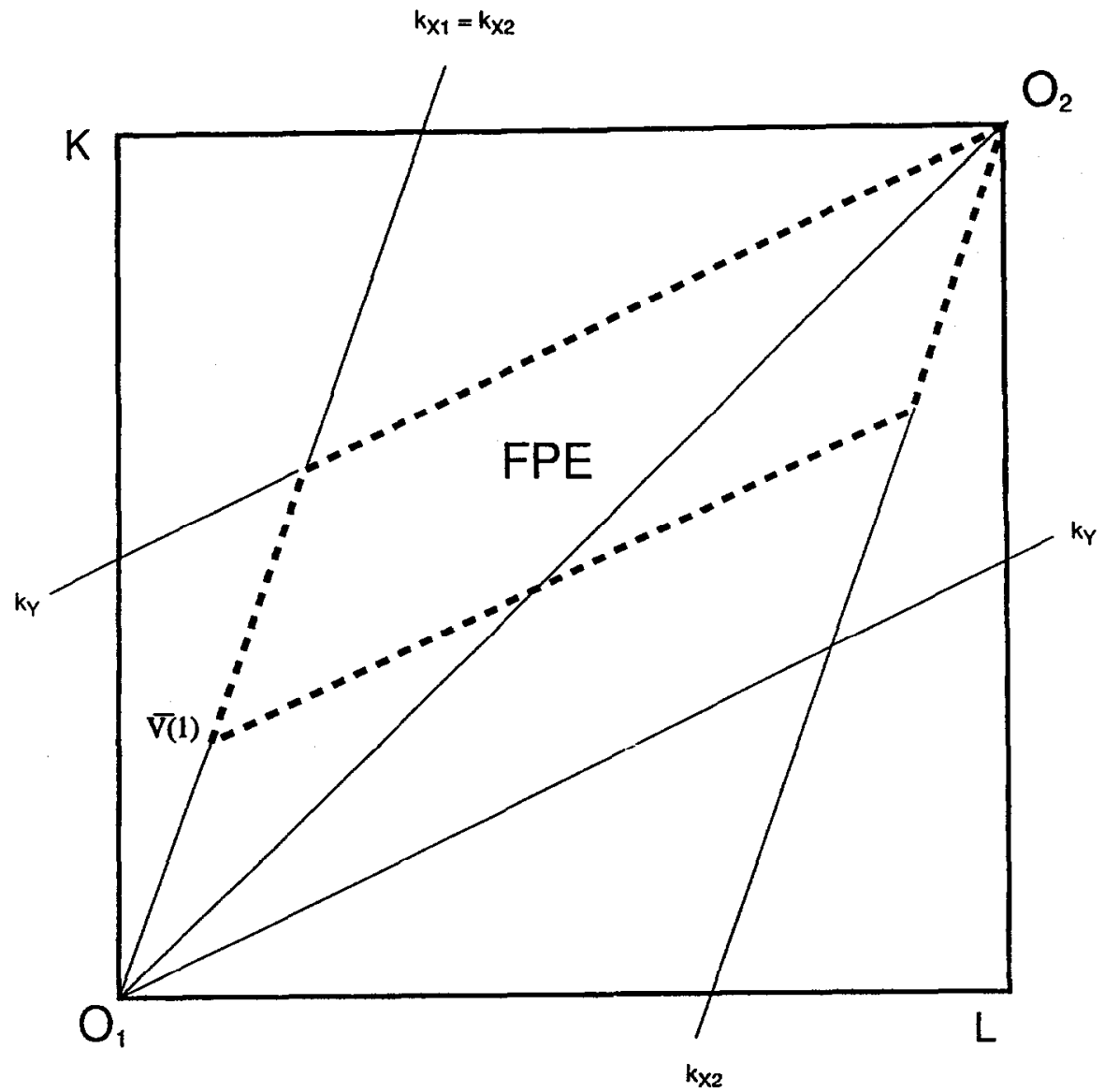

Fig. 1. The integrated equilibrium.

using the integrated equilibrium technique. This is reflected by the vector $\bar{V}(1)$ that extends from $O_{1}$ with slope $k_{X 1}$, reflecting total factor usage in good $X_{1}$. Taking this factor requirement as a new vertex for country One, the equilibrium techniques used in production of goods $X_{2}$ and $Y$ give rise to cones for the two countries in factor space. Any division of the world factor endowment that falls within the parallelogram generated by the intersection of these two cones allows replication of the integrated equilibrium. 


\subsection{The pattern of trade}

Our analysis of the pattern of trade ${ }^{14}$ begins in an area near $\mathrm{O}_{2}$, where an isoincome line continues to be in the FPE set for all points between the factor intensity ratios (see Fig. 2). We examine the effects on trade patterns of movements along the isoincome line. ${ }^{15}$

Within the FPE set, the factor content of consumption is the intersection of the diagonal and the isoincome line. So along the isoincome line, the consumption vector is fixed, country One produces all of the world's $X_{1}$, and there is reallocation of production of goods $X_{2}$ and $Y$. Consider first if the endowment is at point $\mathrm{A}$, on the vector with slope $k_{Y}$ emanating from $\mathrm{O}_{2}$. Country Two produces only good $Y$, which it exports for goods $X_{1}$ and $X_{2}$. This is the case of pure inter-industry trade. As we move away from $\mathrm{A}$, towards B, country Two begins to produce some $X_{2}$, but not yet enough for its own consumption. It still exports good $Y$ for imports of $X_{1}$ and $X_{2}$.

Before we reach the diagonal, we reach a factor endowment ratio, at $\mathrm{B}$, at which country Two just attains self-sufficiency in production of $X_{2}{ }^{16}$ So, at B, country Two exports $Y$ for imports of $X_{1}$. As yet, there is no intraindustry trade. We may refer to this as the case of partial inter-industry trade.

As we move from B to $\mathrm{C}$, country Two produces more of $X_{2}$ than it consumes, and so begins to export it. That is, the labor-abundant country is now exporting one of the capital-intensive goods. This occurs although this country has no (absolute) technical advantage in that good, and the trade pattern is fully determinate. Country two remains a net importer of the intra-industry goods.

When we reach $\mathrm{C}$, each country is self-sufficient in good $Y$. However, country Two must import good $X_{1}$, which it pays for with exports of $X_{2}$. Here, when factor endowment ratios are identical, only intra-industry trade occurs. We call this the case of pure intra-industry trade.

\footnotetext{
${ }^{14}$ The format of the analysis in the following sections, and the statement of the standard factor proportions propositions follows the account in Helpman and Krugman (1985, chapters 2 and 8 ). It should be kept in mind throughout that all statements regarding the pattern and volume of trade pertain only to the factor price equalization set.

${ }^{15}$ If country Two had a large enough share of world income, movements along the isoincome line could bring us to the edge of the FPE set before we reach the cascs of purc intra-industry trade or heterogeneous trade. However, this would not change the analysis for points within the FPE set.

${ }^{16}$ The $X^{2}$ self-sufficiency locus is a ray from $\mathrm{O}^{2}$ within the FPE set. Note that an expansion along a ray from the origin by a factor $\lambda$ raises output in each sector for country Two by the same factor $\lambda$. With homothetic preferences, this must also raise demand in Two for $X_{2}$ by $\lambda$. Thus if the initial point was one of zero excess demand for $X_{2}$, then so must the new point be one in which $X_{2}$ is not traded.
} 


\section{The Pattern of Trade}

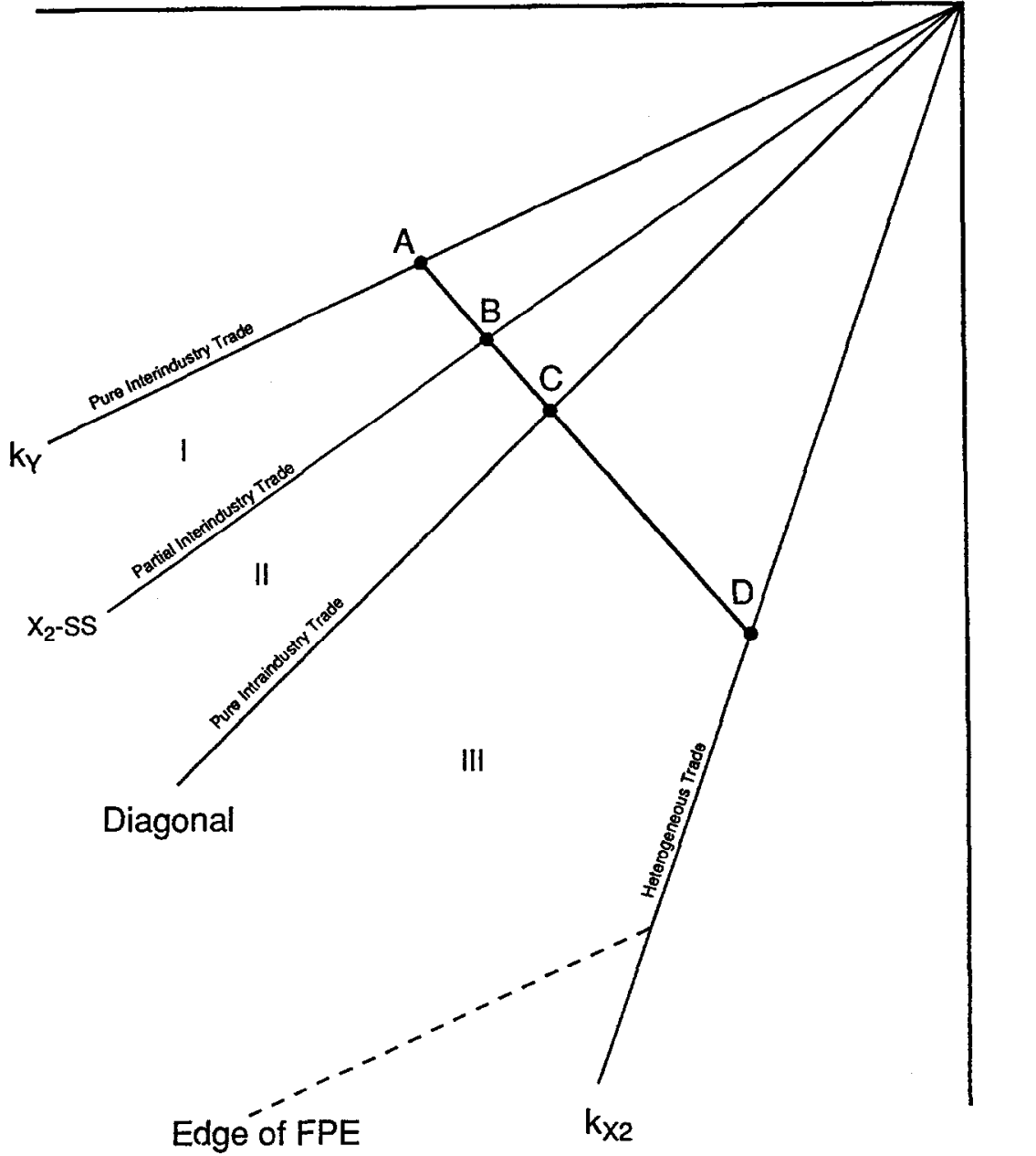

Fig. 2. The pattern of trade.

As we move from C to D, country Two begins to import $Y$ as well as $X_{1}$, and pays for them with exports of $X_{2}$. Thus country One is now the labor-abundant country, and exports one labor-intensive good and one capital-intensive good. Its exports of the capital-intensive good $X_{1}$ are driven by its technical advantage in this good. However it is now a net importer of the intra-industry goods. 
At $\mathrm{D}$, country Two produces only $X_{2}$, which it trades for its entire consumption of both $Y$ and $X_{1}$. As is evident, there is substantial trade in both inter-industry and intra-industry goods. Accordingly, I call this the case of heterogeneous trade.

The results of the Heckscher-Ohlin-Ricardo model on trade patterns are very significant for the problem of intra-industry tradc. In this cxamplc, technical differences are arbitrarily small $;{ }^{17}$ intra-industry trade is in goods of identical factor intensity. Still, when countries have identical endowment ratios, we found that $100 \%$ of trade is intra-industry trade.

\subsection{The volume of trade}

I now derive the level curves of trade volume. It is analytically convenient to separate the effects of factor endowments on the volume of inter-industry trade from the effects on intra-industry trade. Inter-industry trade is twice the value of the good $Y$ traded (it being paid for with exports of $X_{1}$ or $X_{2}$ ). Intra-industry trade, then, consists of the value of goods $X_{1}$ and $X_{2}$ traded against one another. ${ }^{18}$ The derivations that follow, of course, hold only within the FPE set.

The four critical factor ratios noted previously define three regions of the FPE set. Denote the area bounded by the $Y$ factor intensity line emanating from $\mathrm{O}_{2}$ and the $X_{2}$ self-sufficiency line as Region I. From there to the diagonal will be Region II. And from the diagonal to the $X_{2}$ factor intensity line emanating from $\mathrm{O}_{2}$ will be Region III (see Fig. 2).

\subsubsection{The volume of inter-industry trade}

Helpman and Krugman (1985, p.23) noted that in the standard Heckscher-Ohlin setting with factor price equalization, the level curves for total volume of trade are parallel to the diagonal of the box diagram, with increasing volume of trade as we move from the diagonal. This is entirely sensible, as the net factor content of trade is constant along these surfaces, and the volume of trade can be measured by the value of inputs in traded goods.

This does not hold in the Heckscher-Ohlin-Ricardo model, since trade in intra-industry goods may occur with zero net factor content. Instead, within the FPE set, the lines parallel to the diagonal represent a constant value of inter-industry trade (see Fig. 3). Suppose, for example, that country Two is labor abundant. Then it will be the only exporter of $Y$. The volume of inter-industry trade is then (superscripts reflecting the country):

\footnotetext{
${ }^{17}$ This is not to exclude large technical differences on either theoretical or empirical grounds-rather it is to say one need not believe they are large for them to have important effects on trade patterns.

${ }^{18}$ This is comparable to the measure used by Grubel and Lloyd $(1975, \mathrm{p} .20)$.
} 


\section{Level Curves for Volume of Interindustry Trade}

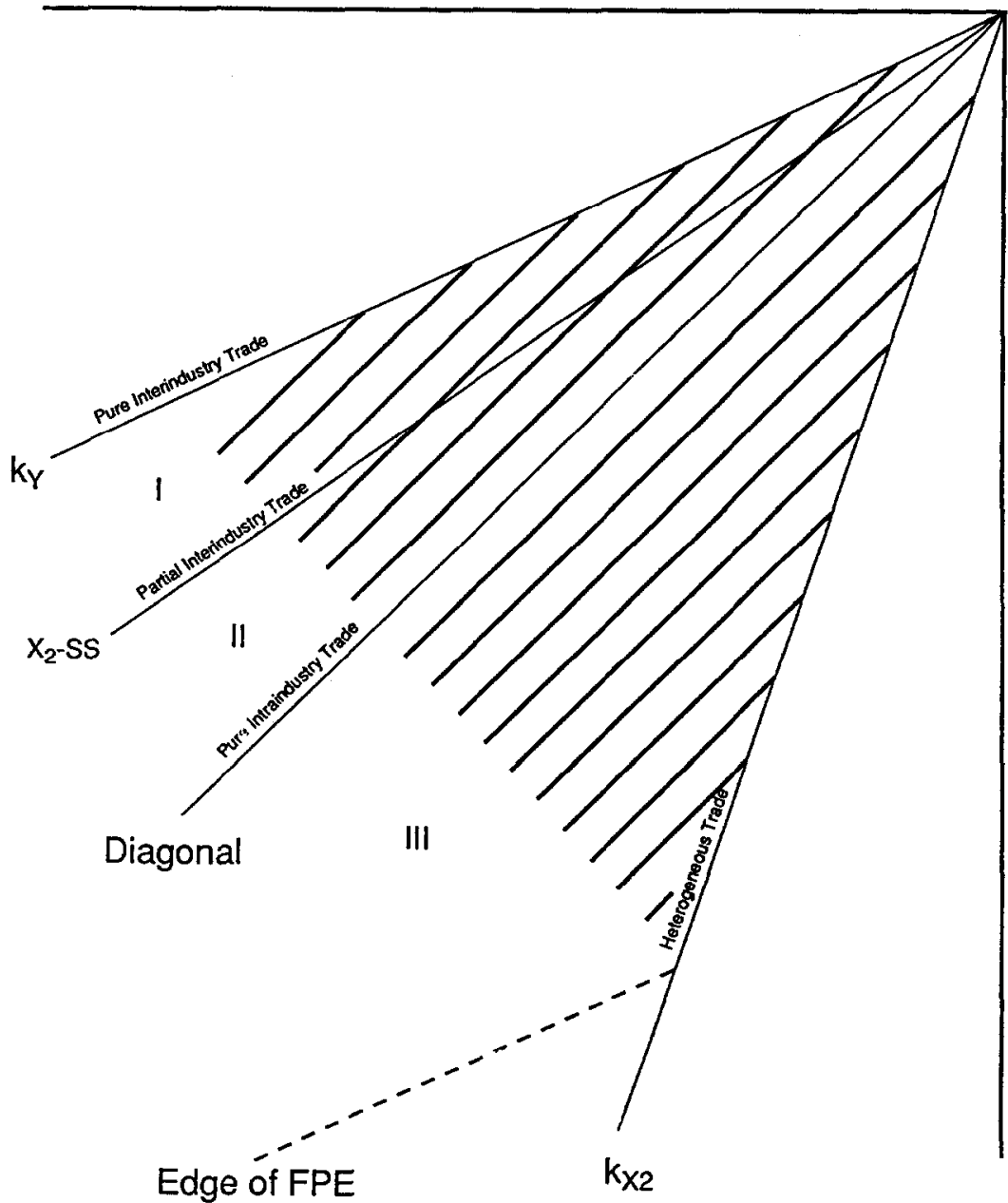

$\mathrm{O}_{2}$

Fig. 3. Level curves for volume of inter-industry trade.

$$
V T_{\text {inter }}=2\left(Y^{2}-s^{2} \bar{Y}\right)
$$

Within the FPE set $Y^{2}$ and $s^{2}$ are linear functions of endowments, so level curves here form a set of parallel lines. Since the diagonal is the level curve with zero inter-industry trade, the other level curves must be parallel. 


\subsubsection{The volume of intra-industry trade}

Now we look at the determinants of the volume of intra-industry trade. It is simplest if we consider this first in the case of pure intra-industry trade, i.e. when the endowment is on the diagonal. Inside the FPE set, and with homothetic preferences, expenditure shares on the goods are fixed and equal across countries. Along the diagonal, $Y$ is not traded. Thus the only trade is Two's exports of $X_{2}$ for imports of $X_{1}$ from One. Balanced trade implies, then, that we can measure the value of trade as twice the value of Two's consumption of $X_{1}$ (since it produces no $X_{1}$ ). Thus the volume of trade rises linearly with Two's income, so long as this is consistent with being in the factor price equalization set. Thus, considering for the moment only the diagonal, the volume of intra-industry trade within this equilibrium reaches its maximum at the interior boundary of the FPE set.

Now we investigate the volume of intra-industry trade off of the diagonal. Recall that the volume of intra-industry trade is defined here as the value of direct exchange of goods $X_{1}$ and $X_{2}$. We have already noted that in Region I there is no intra-industry trade. So we turn to Region II. We are interested in finding the level curves for intra-industry trade. In Region II, we can measure intra-industry trade as twice the value of country Two's excess supply of $X_{2}$. Since within Region 2, country Two's excess supply of $X_{2}$ is fixed on a line parallel to the $X_{2}$ self-sufficiency line, these must be the level curves of intra-industry trade in this region. Finally, we turn to Region III. Here intra-industry trade consists of exports of $X_{2}$ from country Two in exchange for imports of $X_{1}$. Along an isoincome line, imports of $X_{1}$ are fixed, and these can only be paid for by exports of $X_{2}$. Thus the isoincome line in Region III must itself be the level curve for the volume of intraindustry trade (see Fig. 4). A direct consequence of the foregoing analysis is that within the FPE set, the value of intra-industry trade attains a maximum when countries have identical endowment proportions. The proof is straightforward. Its geometric sense can be appreciated by examining Fig. 1. We have already noted that the level curves for intra-industry trade are parallels to the $X_{2}$ self-sufficiency factor ratio, with increasing volume of trade as we move toward the diagonal. Since, necessarily, $k_{Y}<$ slope of $X_{2}$ self-sufficiency $<$ ratio of world endowments, it follows that intra-industry trade reaches a maximum at the interior intersection of the diagonal and the FPE set. That is, within the FPE set, intra-industry trade is maximized at a point where the countries have identical factor endowment ratios.

\subsubsection{Aggregate volume of trade}

The aggregate volume of trade in the Heckscher-Ohlin-Ricardo model is readily ascertained. It may be taken as the sum of exports across countries, or with balanced trade, as twice the exports of either country. We begin by examining the role of similarity of endowment proportions, and then move 
Level Curves for Volume of Intraindustry Trade

$\mathrm{O}_{2}$

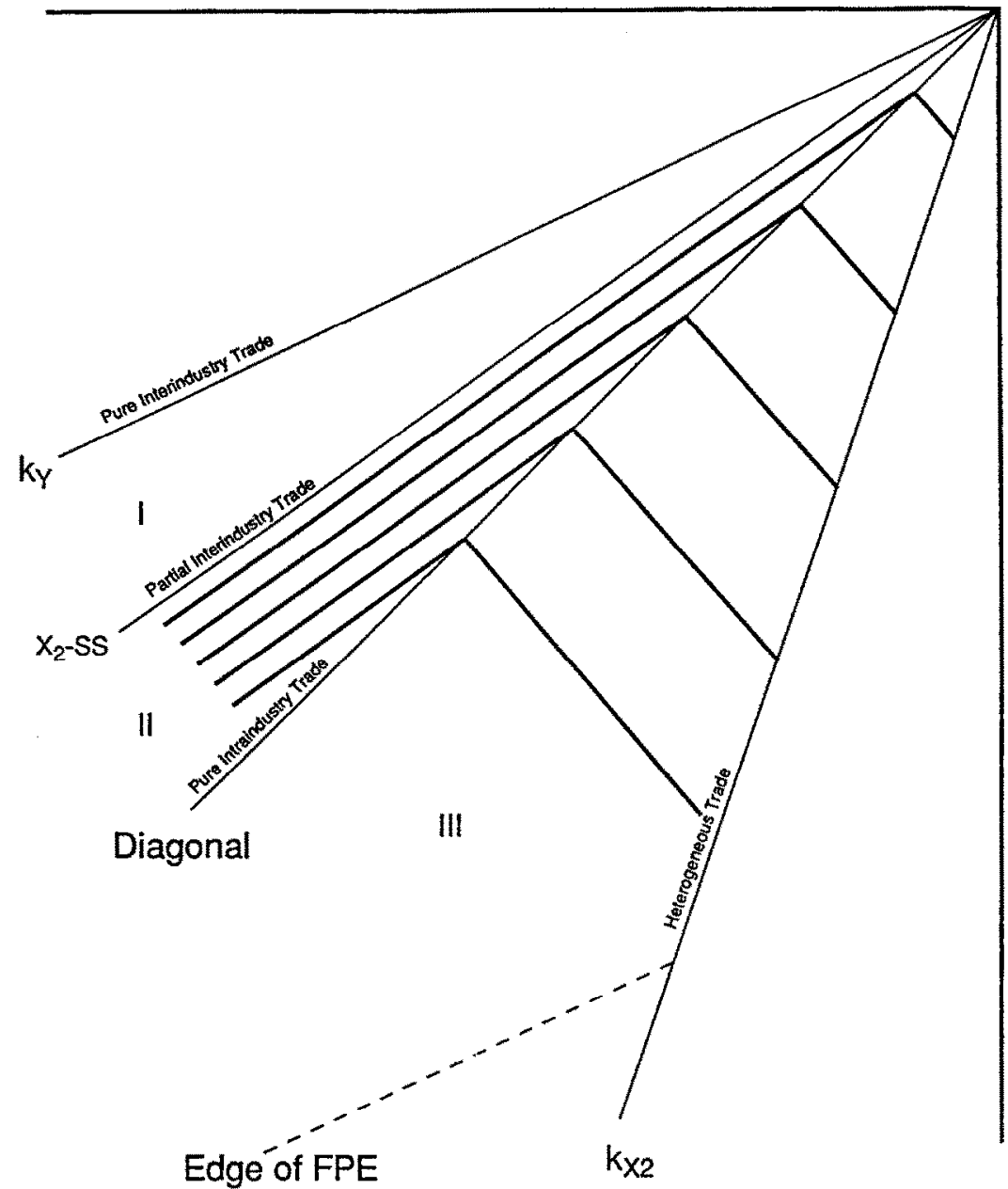

Fig. 4. Level curves for volume of intra-industry trade.

on to consider the role of relative income levels on trade volume (see Fig. 5).

It is convenient to divide the analysis according to the three principal regions in the FPE set. The pattern of trade has already been derived above. In Region I, between the $k_{Y}$ slope and the $X_{2}$ self-sufficiency line, country Two exports only $Y$. Thus the volume of trade in this region is:

$$
V T=2\left(Y^{2}-s^{2} \bar{Y}\right)
$$




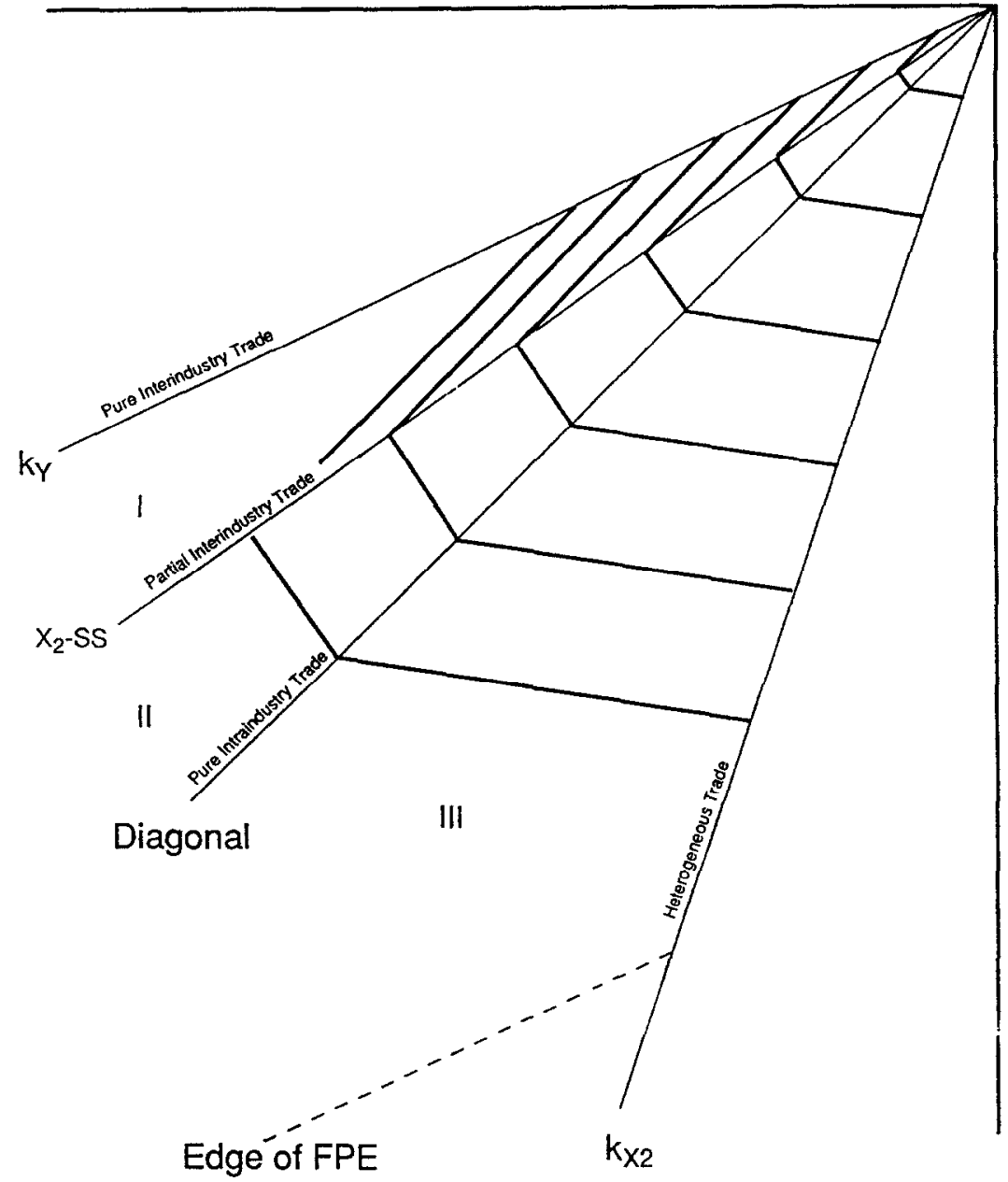

Fig. 5. Level curves for total volume of trade.

A move along the isoincome line towards the diagonal leaves consumption unchanged, but reduces Two's production of $Y$. Thus the trade volume falls as per the standard theory.

In Region II, between the $X_{2}$ self-sufficiency line and the diagonal, country Two exports $X_{2}$ and $Y$ for imports of $X_{1}$ only. Thus the volume of trade is given by:

$$
V T=2 s^{2} \bar{X}_{1}
$$

This is clearly constant for any move along the isoincome line. The fall in 
inter-industry trade is exactly offset by a rise in intra-industry trade, just as the countries are coming to have more similar endowment proportions. This stands in contrast to the standard factor proportions theory, and demonstrates simply that a process of countries coming to have more similar endowment proportions can raise intra-industry trade in a world in which trade arises due to comparative advantage.

In Region III, between the diagonal and the line with slope $k_{X 2}$, country Two is importing $Y$ and $X_{1}$, so exports only $X_{2}$. The volume of trade, then, is given by:

$$
V T=2\left(X_{2}^{2}-s^{2} \bar{X}_{2}\right)
$$

Clearly, this again is rising as we move along an isoincome line to the edge of the FPE set, with relatively more dissimilar endowment proportions.

Now we turn to examining the role of relative incomes in determining trade volume. In Region I there is only inter-industry trade, and so the trade volume is constant along parallels to the diagonal. In this sense, relative income does not matter for trade volume in Region I, as in the traditional theory.

In Region II, the isotrade volume lines are the isoincome lines. Trade volume rises as the share of country Two in income rises, as per the equation above. The fact that income matters here is due to the specialization induced by the special features of the Heckscher-Ohlin-Ricardo model. The fact that trade volume increases monotonically in country Two's share of income arises because of the special assumption that only one country has a technical advantage in any good.

The level curves for total volume of trade in Region III do not have as simple an explanation, although the basic tradeoff is clear. Recall that in Region III, level curves for inter-industry trade are along parallels to the diagonal, while those for intra-industry trade correspond to isoincome lines. The level curves for total trade can be shown to depend on the world endowment ratio, the factor intensity in the $X_{2}$ sector, the expenditure shares on each good and the factor price ratio. In any case, the level curves must have a slope greater than that of the isoincome lines (which have slope $-w / r)$.

\subsection{Contrast with standard Heckscher-Ohlin results}

We now contrast the results of the Heckscher-Ohlin-Ricardo model with the standard results. The Heckscher-Ohlin model yields a simple prediction on the pattern of trade: a country exports the good that uses intensively its relatively abundant factor of production. An important corollary is that countries with identical factor endowment ratios do not trade. When there 
are more goods than factors, the model still predicts that the net factor content of exports reflects relative factor abundance. The caveat is that in this case, the direction of trade in a particular good is not determinate.

The predictions of the Heckscher-Ohlin-Ricardo model share some of these properties, although with important qualifications. In some cases, the predictions diverge strongly. The weaker condition that the net factor content of trade is predicted by relative factor abundance continues to hold fully in the new setting. However, there is an ambiguity in the stronger assertion. The problem is that now there are two capital-intensive goods, $X_{1}$ and $X_{2}$. It is quite possible that the labor abundant country exports one of the capital-intensive goods. Note, though, that unlike the case of more goods than factors with identical technologies, this has nothing to do with indeterminacy in the pattern of production. Trade is fully determinate here. It can arise from two possibilities. First, if One is the labor abundant country, but has an absolute (so comparative) advantage in production of good $X_{1}$, it produces the world supply of that good, so must export it. This corresponds to trade patterns in Region III (see Fig. 2). Second, even if One is the capital abundant country, since it must produce the entire world supply of $X_{1}$, its factor endowment net of this may make it the "labor abundant" country in the residual factor endowments employed to produce the goods with common technologies. Labor abundant country Two would then export capital-intensive good $X_{2}$. This occurs in Region II (see Fig. 2). None the less, the net flow of capital-intensive goods continues to reflect factor abundance. In strong contrast to the standard Heckscher-Ohlin framework, here even countries with identical endowment ratios may engage in substantial trade.

The standard Heckscher-Ohlin model yields two important predictions regarding the relation between factor endowments and the volume of trade. ${ }^{19}$ The first is that, cet. par., the greater the difference in factor endowment ratios, the greater the volume of trade. The second is that (in a sense to be made precise) relative country size has no effect on the volume of trade. ${ }^{20}$

By contrast, in the Heckscher-Ohlin-Ricardo model, these propositions need not hold. These predictions continue to hold exactly as a prediction of inter-industry trade. However, when we measure the total volume of trade, including intra-industry trade, the effects of endowment shifts on trade volume depend crucially on the region in which the endowments lie. If we interpret an increase in the difference in factor endowment ratios as a movement away from the diagonal along an isoincome line, then greater differences in endowment ratios raise trade volume when in Regions I or III

\footnotetext{
${ }^{19}$ The world volume of trade is defined as the sum of exports across countries.

${ }^{20}$ See Helpman and Krugman (1985, section 1.5 )
} 
(see Fig. 2). However, such differences in endowment ratios have no impact on trade volume in Region II. In this region, the rise in inter-industry trade is fully offset by a fall in intra-industry trade. If we interpret a change in relative country size as a movement parallel to the diagonal, then relative country size leaves the volume of trade unchanged in Region I. However, in Regions II and III, country size does matter.

A striking contrast between the predictions of the standard analysis and that in the Heckscher-Ohlin-Ricardo model is that the standard model predicts that countries with identical factor ratios do not trade. In the present model, such countries have no inter-industry trade. However, there may yet be intra-industry trade, which then represents $100 \%$ of trade. In fact, within the FPE set, the volume of intra-industry trade reaches a maximum at a point where countries have identical endowment ratios.

\section{The role of product variety and number}

An important theme within the literature on intra-industry trade has been the great variety and number of goods produced and traded. ${ }^{21}$ This has been taken as additional confirmation of the importance of increasing returns to scale in explaining intra-industry trade. A representative statement comes from Corden (1979, p.9):

'One can argue that intra-industry trade is visibly a manifestation of product differentiation, and that product differentiation must make economies of scale more important.'

However, an important feature of this case has gone almost wholly unnoted. This is the fact that a rise in the number of traded products may also bring to the fore Ricardian determinants of trade. As is well known, the principal results of the Heckscher-Ohlin theory on the pattern of trade are very sensitive to the number of goods relative to the number of factors (Bhagwati, 1972; Samuelson, 1953-1954). I will take the emphasis on trade in differentiated goods to suggest that the number of goods is large relative to the number of factors. ${ }^{22}$ In this case, if technologies are identical and factor prices equalized, then the pattern of trade is indeterminate. The indeterminacy that arises under the stated conditions, however, indicates the relevance of Ricardian determinants of trade. The indeterminacy arises

\footnotetext{
${ }^{21}$ For example, Grubel and Lloyd subtitle their book on intra-industry trade, "The theory and measurement of international trade in differentiated products" [emphasis added].

${ }^{22}$ Such an interpretation is consistent with the frequent use in intra-industry trade theory of models with a continuum of goods and one or a small finite number of factors. See, for example, Krugman (1979). Rader (1979) argues for the relevance of the more-goods-thanfactors case.
} 
precisely due to the excellent substitution possibilities across goods in production. To see this clearly, let us return to our matrix of optimal technical coefficients for a single country:

$$
A(\omega)=\left[\begin{array}{llll}
A_{1} & A_{2} & \ldots & A_{N}
\end{array}\right]=\left[\begin{array}{cccc}
a_{11} & a_{12} & \ldots & a_{1 N} \\
a_{21} & a_{22} & \ldots & a_{2 N} \\
\cdot & \cdot & \cdot & \cdot \\
a_{M 1} & a_{M 2} & \ldots & a_{M N}
\end{array}\right]
$$

When goods outnumber factors, there is necessarily linear dependence in the columns of the $A(\omega)$ matrix-some of the columns may be expressed as a linear combination of other columns. Then in shifting production between one good and the corresponding set of other goods, there is no rising marginal opportunity cost until at least one of the goods is no longer produced. Thus, technical differences-however small-here also induce specialization and trade. ${ }^{23}$

It is straightforward to show that this could give rise to intra-industry trade. Consider a world with two countries. There are $N$ goods and $M$ factors, with $N>M$. The countries share exactly $M$ technologies, and $N-M$ technologies differ ${ }^{24}$ The technical differences are assumed to be Hicks-neutral. I assume that when employing the integrated equilibrium techniques, the vectors of factor usage of the $M$ goods with identical technologies are linearly independent. Preferences are identical and homothetic.

The Factor Price Equalization Set is given as:

$$
\begin{aligned}
& F P E= {\left[\left(V^{1}, V^{2}\right) \mid \exists \lambda_{i j} \geq 0 \quad\right. \text { such that }} \\
& \sum_{i} \lambda_{i j}=1 \quad \forall i \in I^{S}, \\
& \lambda_{i 1}=1 \quad \lambda_{i 2}=0 \quad \forall i \in I^{1} \\
& \lambda^{i}{ }_{1}=0 \quad \lambda_{i 2}=1 \quad \forall i \in I^{2} \\
&\left.V^{j}=\sum_{i} \lambda_{i j} \bar{V}(i) \quad j=1,2\right]
\end{aligned}
$$

\footnotetext{
${ }^{23}$ That indeterminacies in production may arise with $N>M$ has been widely recognized. This result has largely becn rcgarded as a curiosity or a nuisance, which would be resolved, for example, by introducing transport costs. However, the essential insight exploited here was first noted, I believe, by Vanek and Bertrand (1971) in three terse paragraphs at the end of their article.

${ }^{24}$ If we relax the assumption that there are exactly $M$ identical technologies (and so allow more than $M$ identical technologies), an element of indeterminacy in the pattern of trade of individual goods with identical technologies may re-emerge. The factor price equalization set will have full dimension so long as there are $M$ vectors of optimal factor employment among these $M^{\prime}$ goods which are linearly independent.
} 
This says that FPE is the set of partitions of world factor endowments between the two countries, such that when employing the integrated equilibrium techniques:

- Production of the goods with identical technologies may be divided between the countries.

- Each country produces the entire integrated equilibrium supply of the goods in which it has a technical advantage.

- This is consistent with full employment of factors in both countries.

The geometric intuition carries over to this case. When technologies differ, only the efficient technology can be employed if we are to replicate the integrated equilibrium. Thus, each country must have sufficient factors to produce, using the integrated equilibrium techniques, the integrated equilibrium levels of output of the goods in which it has an absolute technical advantage. Taking these initial factor requirements as new vertices, the $M$ technologies which are common to the two countries then define an $M$-dimensional cone, reflecting the integrated equilibrium techniques, for each of the two countries. Then, any division of the world factor endowment that lies within both cones insures that trade replicates the integrated equilibrium. If the endowment lies strictly within each cone, there is diversification in production of all goods with common technologies; there is specialization in all goods in which technologies differ.

The possibility of explaining intra-industry trade in this setting is immediate. No restrictions whatsoever have been placed on the factor intensities of the goods in which production is specialized. It is perfectly possible that these are goods of similar factor intensity. Since both countries consume the goods in equal proportions, there must be trade in these goods.

An important special case is when the countries have identical factor endowment proportions (i.e. their endowment vectors differ by a scalar), and are within the $M$-dimensional cones. Of necessity, there is still trade in all goods in which technologies differ. As well, there is trade in at least some of the goods in which technologies are identical, except in the knife-edge case where the net factor content of trade in the goods in which technologies differ is zero.

The key point to recognize is that the emphasis in the intra-industry trade literature on the large number of goods produced and traded also suggests an interpretation of this trade based on the traditional Ricardian theory of comparative advantage. The literature has emphasized that when there are more goods than factors, factor prices are equalized and technologies are identical across countries, the pattern of trade is indeterminate. Intraindustry trade seems pointless. This emphasis, however, has been misplaced. Rather we should see that this is a setting in which technical 
differences may be decisive in determining the pattern and volume of trade. Here also, substantial intra-industry trade could arise from simple Ricardian comparative advantage.

\section{Conclusion}

Growing appreciation of the importance of intra-industry trade has made its explanation an important theoretical objective. In the last decade there has been wide acceptance of a claim that increasing returns are necessary to account for this trade. ${ }^{25}$

This paper has shown that-to the contrary-intra-industry trade arises quite naturally in a constant returns setting. Intra-industry trade is shown to bear a special relation to traditional Ricardian determinants of trade. These are relevant because essential elements of the intra-industry setting-the fact that it is trade in goods of similar factor intensity, and the focus on the large number of goods produced and traded-give rise to excellent substitution possibilities across goods in production. In such a setting, small technical differences induce specialization and trade.

\footnotetext{
${ }^{25}$ An additional factor often cited in favor of increasing returns models is the normative impact of trade liberalization (e.g. Helpman and Krugman, 1985, p.3). In a Heckscher-Ohlin framework, the Stolper-Samuclson theorem suggests that even as trade generates aggregate gains, that absent redistribution one of the two factors must suffer a decline in real income. If there is integration among identical countries, no factor need lose, but this is because there will be no trade. However, it is suggested, modern experience belies this. Integration among like countries has generated nearly universal gains, so engendered little significant opposition; integration among dissimilar countries, by contrast, has spawned dissension. Scale economies offer a particularly attractive explanation of the gains from integration of like countries, since it is possible to reap the gains of scale economies with little or no sectoral reallocation of resources. The same, however, is true in the general Heckscher-Ohlin-Ricardo model. Gains here come from two sources: sectoral reallocation corresponding to conventional HeckscherOhlin gains, and increased efficiency of use of existing resources, as integration allows greater specialization on Ricardian grounds for a fixed intersectoral distribution. If actual technical differences were very small, then so too would be the associated gains from integration of identical countries. However, the assumption of small technical differences was not an empirical assertion, but rather to establish that small differences are sufficient in the theoretical model. Moreover, they have an exact parallel in the degree of economies of scale. If this is sufficiently small, then so too will be the gains from integration of like countries. In the monopolistic competition framework, some of these gains in the increased cfficiency of use of existing resources may come in the form of gains from increased variety. At times it is also suggested that this is a reason to prefer this framework to competitive models. However, it should be evident from the work of Young (1991) that once exact symmetry conditions are abandoned, either on the cost or demand side, that similar gains from increased variety of goods are quite consistent with the competitive, constant returns to scale framework. In sum, the modern experience of integration does not on its face provide a reason to prefer the scale economies model.
} 
This was first examined in an ideal case-accounting for trade in perfectlyintraindustry goods. I then developed the simplest model that gives a unified account of inter-industry and intra-industry trade, the Heckscher-OhlinRicardo model. Finally, I showed that the emphasis in the literature on the variety and number of goods produced and traded likewise suggests Ricardian determinants of trade, and the possibility of substantial intraindustry trade.

The distinction between the increasing and constant returns theories has direct relevance for trade policy. Increasing returns are typically associated with imperfect competition, and so often invite government intervention in trade. Constant returns are associated with perfect competition, and (other distortions absent) suggest a policy of free trade.

Increasing returns, in short, are not necessary to account for intra-industry trade. $^{26}$

\section{Acknowledgments}

I would like to thank Jagdish Bhagwati, Andre Burgstaller, Ron Findlay, Mike Gavin, Tatsuo Hatta, Doug Irwin, and two anonymous referees for helpful comments. I would also like to thank participants in seminars at MIT, Harvard, Stanford, Pennsylvania, Columbia, Michigan, and the University of Chicago School of Business. A previous version of this paper appeared in the International Finance Discussion Papers series of the Board of Governors of the Federal Reserve, no. 411. The views expressed here are not necessarily those of the Federal Reserve.

\section{References}

Balassa, B. and L. Bauwens, 1987, Intra-industry specialisation in a multi-country and multi-industry framework, Economic Journal 97, 923-939.

Balassa, B. and L. Bauwens, 1988, Changing trade patterns in manufactured goods: An econometric approach (Elsevier, New York).

Bhagwati, J.N., 1964, The pure theory of international trade: A survey, Economic Journal 74, 1-84.

Bhagwati, J.N., 1972, The Heckscher-Ohlin theorem in the multi-commodity case, Journal of Political Economy 80, 1052-1055.

Brander, James A., 1987, Book review of Greenaway and Milner (1986), Journal of International Economics 23:1/2, 182-185.

${ }^{26}$ The fact that increasing returns are not necessary to account for intra-industry trade does not imply that these models lack interest. Rather it suggests that efforts to distinguish these models empirically must move beyond the facts implied by simple specialization. 
Caves, Richard, 1981, Intra-industry trade and market structure in the industrial countries, Oxford Economic Papers 33, 203-223.

Chipman, John S., 1985, Intra-industry trade, factor proportions, and aggregation, Mimeo.

Chipman, John S., 1988, Intra-industry trade in the Heckscher-Ohlin-Lerner-Samuelson model, Mimeo, University of Minnesota and Universitat Konstanz.

Corden, W.M., 1979, Intra-industry trade and factor proportions theory, in: H. Giersch, ed., On the economics of intra-industry trade: Symposium 1978 (Mohr, Tubingen) 3-17.

Dixit, Avinash K. and V. Norman, 1980, The theory of international trade (Cambridge University Press, Cambridge).

Ethier, W., 1982, National and international returns to scale in the modern theory of international trade, American Economic Review 72:3.

Ethier, W., 1984, Higher dimensional issues in trade theory, in: Handbook of international economics, Vol. 1 (Elsevier Science, New York) 131-184.

Falvey, R.E. and H. Kierzkowski, 1987, Product quality, intra-industry trade and (im)perfect competition, in: H. Kierzkowski, ed., Protection and competition in international trade (Basil Blackwell, New York) 143-161.

Finger, J.M., 1975, Trade overlap and intra-industry trade, Economic Inquiry 13, 581-589.

Greenaway, D. and C. Milner, 1986, The economics of intra-industry trade (Basil Blackwell, New York).

Greenaway, D. and C. Milner, 1987, Intra-industry trade: Current perspectives and unresolved issues, Weltwirtschaftliches Archiv 123:1, 39-57.

Grubel, H.G. and P.J. Lloyd, 1975, Intra-industry trade: The theory and measurement of international trade in differentiated products (Wiley, New York).

Harrigan, James, 1991, Scale economies and the volume of trade, Mimeo, University of Pittsburgh.

Helpman, E., 1988, Imperfect competition and international trade: Evidence from fourteen industrial countries, in: A.M. Spence and H.A. Hazard, eds., International competitiveness (Ballinger, New York).

Helpman, E. and P. Krugman, 1985, Market structure and foreign trade (MIT, Cambridge, MA).

Helpman, E. and Krugman, P. 1989, Trade policy and market structure, (MIT, Cambridge, MA).

Krugman, P.R., 1979, Increasing returns, monopolistic competition, and international trade, Journal of International Economics 9:4, 469-479.

Krugman, P.R. and Maurice Obstfeld, 1991, International economics: Theory and policy, 2nd edn. (Harper Collins, New York).

Lancaster, Kelvin, 1980, Intra-industry trade under perfect monopolistic competition, Journal of International Economics 10, 151-175.

Leamer, E., 1992, Testing trade theory, NBER Working Paper No. 3957.

Lizondo, J.S., H.G. Johnson and Y. Yeh, 1981, Factor intensities and the shape of the production possibility curve, Economica 48, 199-202.

Loertscher, Rudolf and Frank Wolter, 1980, Determinants of intra-industry trade: Among countries and across industries, Weltwirtschaftliches Archiv 116:2, 280-293.

Markusen, James R. and Randall M. Wigle, 1990, Explaining the volume of North-South trade, Economic Journal 100, 1206-1215.

Marvel, Howard P. and Edward John Ray, 1987, Intra-industry trade: Sources and effects on protection, Journal of Political Economy 95:6, 1278-1291.

Minhas, Bagicha, 1962, The homohypallagic production function, factor intensity reversals, and the Heckscher-Ohlin theorem, Journal of Political Economy 70(2), 138-156.

Rader, T., 1979, Factor price equalization with more industries than factors, in: Jerry Green and Jose Scheinkman, eds., General equilibrium, growth and trade: Essays in honor of Lionel McKenzic (Academic Press, New York) 347-354. 
Rodgers, Joan R., 1988, Intra-industry trade, aggregation and the HOS model, Journal of Economic Studies 15:5, 5-23.

Ruffin, Roy J., 1988, The missing link: The Ricardian approach to the factor endowments theory of trade, American Economic Review 78(4), 759-772.

Samuelson, P.A., 1948, International trade and equalization of factor prices, Economic Journal LVIII (230) 163-184.

Samuelson, P.A., 1949, International factor price equalization once again, Economic Journal LIX (234) 181-197.

Samuelson, P.A., 1952, A comment on factor price equalization, Review of Economic Studies XIX (2), 121-122.

Samuelson, P.A., 1953, Prices of factors and goods in general equilibrium, Review of Economic Studies 21:2, 1-20.

Tharakan, P.K.M., 1989a, ed., Intra-industry trade: Theory, evidence and extensions (Macmillan, London).

Tharakan, P.K.M., 1989b, ed., Intra-industry trade (North-Holland, New York).

Vanek, J. and T. Bertrand, 1971, Trade and factor prices in a multi-commodity world, in: J.N. Bhagwati, R.W. Jones, R.A. Mundell and J. Vanek, eds., Trade, balance of payments and growth: Papers in international economics in honor of Charles P. Kindleberger (Elsevier, New York).

Woodland, A.D., 1982, International trade and resource allocation (North-Holland, New York).

Young, A., 1991, Learning by doing and the dynamic effects of international trade, Quarterly Journal of Economics 106:2, 369-405. 